\title{
May Organically Farmed Animals Pose a Risk for Campylobacter Infections in Humans?
}

\author{
By Anders Engvall \\ National Veterinary Institute, Department of Disease Control and Biosecurity, S- 55189 Uppsala.

\begin{abstract}
Organic farming of meat producing poultry like broilers, means that the animals should be kept outdoors as much as possible. This pose a risk that they get infected with Campylobacter. At slaughter, carcasses may be contaminated with campylobacter. If cross contamination occurs in the kitchen or if the meat is undercooked people may ingest the bacteria and suffer from enteritis. It seems possible that close to 100 percent of organically farmed flocks may be infected with campylobacter while under Swedish conditions only 10 percent of conventionally reared flocks are infected.
\end{abstract}

Campylobacter, organic farming, poultry, broiler, out-door rearing.

\section{Introduction}

Campylobacter, a Gram-negative, curved, spiral, non-sporing bacteria, is a common cause of diarrheal illness among humans in industrialised and developing countries. Its importance as a cause of gastroenteritis was recognised in the 1970's when the development of selective growth media allowed laboratories to test large amounts of stool specimens (Skirrow et al. 1998). The genus Campylobacter consists of several species and the taxonomy has changed considerably over time. At present there are 15 species and 6 subspecies. Only a few of these are considered significant as causes of gastroenteritis in humans; they are $C$. jejuni, $C$. coli, C. lari, C. upsaliensis and C. concisus. All but $C$. concisus have also been found in animals. $C$. jejuni is by far the most often isolated species, followed by C. coli (Vandamme \& Goossens 1992). Besides the common symptoms of gastroenteritis, serious sequele to infections have been reported. In approximately $1 \%$ of patients with campylobacteriosis, a reactive arthropathy is seen and in an estimated 1 promille, Guillain-Barré syndrome, a debilitating disorder, occurs (Altekruse et al. 1999).
Campylobacter species have been found in a multitude of animal species including foodproducing animals. Several sources of infection, such as surface water, un-pas-teurised milk, chicken, turkey and red meat, have been identified, and contacts with dogs and cats have also been found to be risk factors. Several studies have shown that during the slaughter process, carcasses may be contaminated with campylobacter and that this contamination still persists at the retail level. This has been especially signifi-cant for broilers, and broiler meat is considered one of the most important sources of infection for humans (Altekruse et al. 1994, Skirrow et al. 1998).

The EU regulation 2092/91 with Annex 1B (399R1804) (EU-regulation) stipulates conditions for organic farming of animals within the European Union. In addition to this regulation, there are in Sweden two non-governmental organisations, KRAV and Svenska Demeterförbundet, that have stipulated national rules for organic farming. KRAV is subsidiary to International Federation of Organic Agriculture Movements (IFOAM). Important parts of the 
organic farming philosophy are that animals should have access to outdoor areas and be able to graze and exert natural behaviour. In addition only organic fertilisers, i.e. manure, sludge etc., may be used. Animals should be slaughtered as close to the production site as possible, thereby avoiding the stress that long distance trans-portation may incur.

In Sweden, goals have been set up for an increase in organic farming. In a recent report by the Swedish Board of Agriculture (Anonymous 1999), organic production of beef, mutton, pork, poultry meat and table eggs were planned to be $20 \%, 20 \%, 5 \%, 5 \%$ and $10 \%$ respec-tively of total production in 2005 .

Is it possible that the organic farming of animals poses a higher risk for campylobacter infections in humans than conventional farming? The aim of the present study is to review factors related to organic farming that may possibly influence campylobacter infections in animals, contamination of food and risks for human beings.

\section{Conventional farming}

In conventionally farmed animals for production, campylobacter infection rates may vary considerably (Berndtson 1996). Pigs are normally colonised to a very high extent $(C$. coli) while for cattle and sheep varying figures (10$90 \%$ ) have been shown. The reason for this variation in figures is not clear. In poultry, colonisation rates normally are very high. In poultry, cattle and sheep, $C$. jejuni is normally the dominant species. Table eggs are not infected with campylobacter, but their shells may be contaminated with droppings containing campylobacter.

In broilers the rate of colonisation of campylobacter is influenced by rearing systems and hygienic measures. In the Nordic countries of Norway, Sweden and Finland, flock prevalence has been decreased to less than $10 \%$, mainly due to a high biosecurity level of rearing establishments, while flock prevalence is $40 \%$ or more in many other coun-tries. Bacterial contamination of carcasses from broilers, coming from different flocks but slaughtered at the same slaughter house, is unavoidable with present slaughter technique. Thus, a single flock infected with campylobacter may constitute a significant contamination risk for other, campylobacter free flocks.

\section{Organic farming}

Organic or ecological farming of cattle, sheep and pigs probably will not exert a higher risk for campylobacter infections. Conventionally farmed cattle and sheep are kept out-doors to a high extent and other factors related to organic farming probably will not influence carrier rates significantly. A majority of pigs are already today carriers, and this will probably not change, if pigs are kept outdoors. However, as regards pigs, there are some indications that a high level of biosecurity might decrease number of carriers (Urlings et al. 1998).

Egg production under organic conditions, will probably not increase the risk for Campylobacter infections. In most cases, campylobacter bacteria contaminating the shell, will die off, due to unfavourable conditions, e.g. dehydration.

In broilers and other meat producing poultry organic production may exert a major influence on carrier rates, at least under Swedish conditions. At present, annual inci-dence of infected broiler flocks in Sweden is 9\%. If broilers were allowed to stay out-doors, flock carrier rates may increase to $70-100 \%$. A $100 \%$ carrier rate in organic flocks is not unreasonable as shown by Heuer et al. (2000) in a Danish study. This is due to the high contamination rate of Campylobacter, occurring in the environment. If slaughtered in slaughter houses where conventional broilers are processed, also these broilers 
would be contaminated to a high degree. At present it is calculated that approximately six million contaminated broiler carcasses are produced in Sweden annually. If $10 \%$ of total broiler production were to be produced organically, an addi-tional six million contaminated carcasses could reach the market, introducing an addi-tional risk for human beings.

Other possible risks that may show up should be mentioned. In a society where organic farming constitutes a considerable part of food production, new consumer habits may develop, e.g. consumption of unpasteurised milk. Unpasteurised milk is a well known vehicle for Campylobacter and should consumption increase, so would probably inci-dence of campylobacter infections.

Another risk may be the use of very small slaughter houses or even slaughter at home of animals. It is generally considered more difficult to keep slaughter hygiene at a high level in very small slaughter houses, and so the risk of faecal contamination of carcasses would increase.

In conclusion the major risk seems to be associated with broilers and other poultry for meat production. There seems for the moment, not to exist technical ways of solving this problem, and more research is needed.

\section{References}

Altekruse SF, Hunt JM, Tollefson LK, Madden JM: Food and animal sources of human Campylobacter jejuni infection. Public Vet. Medicine: Public Health. JAVMA. 1994, 204, 57-61.

Altekruse SF, Stern NJ, Fields PI, Swerdlow DL: Campylobacter jejuni - An Emerging Foodborne Pathogen. Emering Infectious Diseases, volume $5,1999$.
Anonymous 1991. Mål för ekologisk production 2005 (Goals for ecologic production 2005). Jordbruksverket, Djurmiljöenheten. Rapport 1999:16. (In Swedish).

EU-regulation: EU-regulation on organic farming (2092/91, Annex 1B, 399R1804).

Berndtson E: Campylobacter in Broiler Chickens. Thesis. Uppsala. 1996.

Heuer O, Pedersen K, Andersen JS, Madsen M: Prevalence of thermophilic Campylobacter and antimicrobial susceptibility patterns of zoonotic and indicator bacteria from organic and conventional broilers in Denmark. NKVet. Veterinary challenges in organic farming. Hveragerdi, Iceland, 5-8 October 2000.

Skirrow MB: Campylobacteriosis. In: Zoonoses. Ed: Palmer, S.R., Lord Soulsby and Simpson DIH. Oxford University Press 1998. pp 37-46.

Urlings BAP, Weijtens MJBM, Bijker PGH, van der Plas J: Spread of Campylo-bacter in a superhealth-status (S-H-S) pig farm. In: Campylobacter, Helicobacter related organisms. Ed: Lastovica, Newell, Lastovica. $9^{\text {th }}$ International workshop, 1997. Institute of Child Health. University Cape Town 1998. pp 72-74.

Vandamme P, Goossens H: Taxonomy of Campylobacter, Arcobacter, and Helicobacter: A Review. Zbl. Bakt. 1992, 276, 447-472.

\section{Sammanfattning}

Organisk uppfödning av fjäderfä för köttproduktion innebär bland annat att djuren skall hållas utomhus så mycket som möjligt. Detta utgör en risk för att djuren skall infekteras med Campylobacter. Vid slakt kan slaktkropparna kontamineras med Campylobacter. Om korskontaminering sker vid tillredningen eller om köttet inte upphettas tillräckligt kan människor insjukna. Det verkar troligt att nästan 100\% av flockar som uppföds organiskt blir smittade med campylobacter, medan under svenska förhållanden, endast 10 procent av konventionellt uppfödda flockar är smittade. 